\title{
Structure-Activity Relationships of New A,D-Ring Modified Steroids as Aromatase Inhibitors: Design, Synthesis, and Biological Activity Evaluation
}

\author{
Margarida M. D. S. Cepa ${ }^{\dagger}$ Elisiário J. Tavares da Silva, ${ }^{\dagger}$ Georgina Correia-da-Silva ${ }^{\dagger}$ \\ Fernanda M. F. Roleira, ${ }^{\ddagger}$ and Natércia A. A. Teixeira*,† \\ Biochemistry Laboratory, Faculty of Pharmacy, University of Oporto, 4050-047 Oporto, Portugal, Institute for Molecular and \\ Cellular Biology, 4150-180 Oporto, Portugal, and Centro de Estudos Farmacêuticos, Pharmaceutical Chemistry Laboratory, \\ Faculty of Pharmacy, University of Coimbra, 3000-295 Coimbra, Portugal
}

Received February 10, 2005

Inhibition of aromatase is an efficient approach for the prevention and treatment of breast cancer. New A,D-ring modified steroid analogues of formestane and testolactone were designed and synthesized and their biochemical activity was investigated in vitro in an attempt to find new aromatase inhibitors and to gain insight into their structure-activity relationships (SAR). All compounds tested were less active than formestane. However, the 3-deoxy steroidal olefin $3 \mathbf{a}$ and its epoxide derivative $4 \mathbf{a}$ proved to be strong competitive aromatase inhibitors $\left(K_{\mathrm{i}}=50\right.$ and $38 \mathrm{nM}$ and $\mathrm{IC}_{50}=225$ and $145 \mathrm{nM}$, respectively). According to our findings, the C-3 carbonyl group is not essential for anti-aromatase activity, but $5 \alpha$-stereochemistry and some planarity in the steroidal framework is required. Furthermore, modification of the steroidal cyclopentanone D-ring, by construction of a $\delta$-lactone six-membered ring, decreases the inhibitory potency. From the results obtained, it may be concluded that the binding pocket of the active site of aromatase requires planarity in the region of the steroid A,B-rings and the D-ring structure is critical for the binding.

\section{Introduction}

Estrogens are required for normal tissue growth and development, but they are also responsible for the promotion of certain tumors, such as prostatic hyperplasia, prostate, endometrial, and especially breast cancers. ${ }^{1}$ In fact, $30-50 \%$ of breast cancers are considered to be estrogen-dependent, ${ }^{2,3}$ and regression can be achieved by reducing blood and tissue estrogen levels. The highest incidence of breast cancer occurs in postmenopausal women, ${ }^{4}$ whose ovarian function and hypophyseal control of estrogen production has ceased. In these women, estrogen biosynthesis occurs mostly in peripheral tissues such as liver, skin, muscle, and adipose tissue..$^{5-7}$ For this reason, total blockage of estrogen biosynthesis is easier to achieve by chemical means rather than by surgical therapy. 8 Two main chemical approaches have been successfully applied as endocrine therapy of estrogen-dependent breast cancer. One is directed to the estrogen receptor by use of selective estrogen receptor modulators (SERMs), among which tamoxifen is the most popular one. The other is directed to aromatase, the key enzyme responsible for estrogen biosynthesis. ${ }^{9,10}$ Since estrogens are formed in the last step of the biosynthetic sequence of steroid production, aromatase inhibition provides a basis for the development of selective chemotherapies for treatment and prevention of estrogen-sensitive breast cancers. ${ }^{11}$ Furthermore, the therapeutic potential of aromatase inhibitors stretches beyond postmenopausal women with breast cancer, because these inhibitors have also

* To whom correspondence should be addressed: phone +351222078907; fax +351222003977; e-mail natercia@ff.up.pt.

$\dagger$ University of Oporto and Institute for Molecular and Cellular Biology.

¥University of Coimbra.
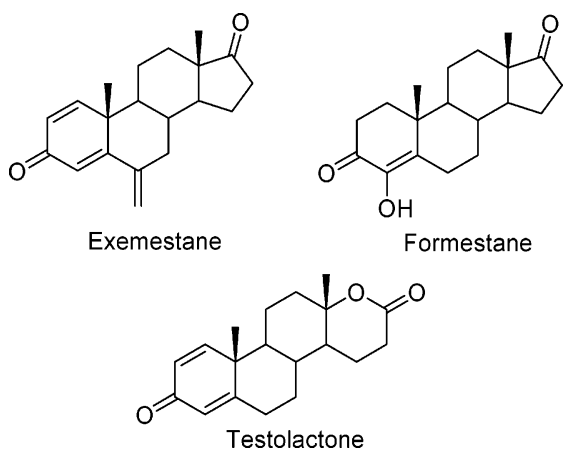

Figure 1. Steroids clinically used as aromatase inhibitors.

been shown to be clinically relevant in the management of other estrogen-dependent pathological processes such as endometriosis, ${ }^{12}$ gynecomastia, prostatic hyperplasia, and prostate cancer. ${ }^{13}$ For these reasons, several steroidal aromatase inhibitors, based on the structure of the natural substrate androstenedione, have been designed and synthesized in several laboratories. Exemestane and the well-established formestane (Figure 1) are two examples of these kinds of compounds that are known to be very efficient in the treatment of patients in whom other anti-estrogen therapies failed. ${ }^{8,14}$

In the present study our focus is on the design, synthesis, and biochemical evaluation of a new series of substituted steroids containing modifications in the A- and D-rings. The new compounds were obtained by chemical modifications to the structure of the natural enzyme substrate, androstenedione, to achieve new aromatase inhibitors in order to further study the structure-activity relationships (SAR). The studied SAR were correlated with three main features, namely, the A-ring substitution pattern and the planarity of this 
Scheme 1. Synthesis of Aromatase Inhibitors from androstenedione $\mathbf{1}^{a}$

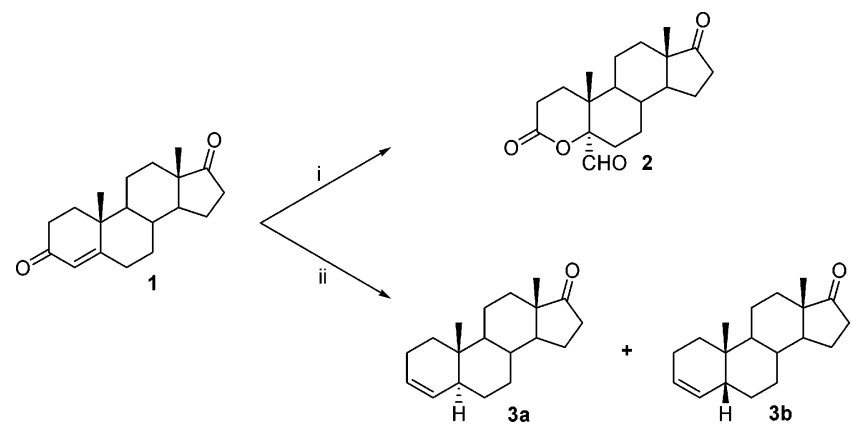

${ }^{a}$ Reagents and conditions: (i) $\mathrm{MeOH}, \mathrm{KMnO}_{4}, \mathrm{KOH}, 15{ }^{\circ} \mathrm{C}, 10$ min; (ii) $\mathrm{CH}_{3} \mathrm{COOH}$, $\mathrm{Zn}$ dust, $118{ }^{\circ} \mathrm{C}, 15 \mathrm{~min}$.

ring, the C-5 stereochemistry in the A/B-ring fusion, and the D-ring structure. Numazawa and co-workers ${ }^{15-18}$ have performed several SAR studies in steroid aromatase inhibitors indicating the existence of a binding pocket in the active site of the enzyme, which can accommodate several chemical groups placed at the C-4 position of the steroids. According to this information, we embarked on the design, synthesis, and biochemical evaluation of some C-4 oxo- (2), C-4 keto- (6 and 10), C-4 hydroxy- (5a, 5b, and 8), and C-4 hydroxycyano(11) substituted androstanes (Schemes 1 and 2). In the same way, the C-3 carbonyl group of the substrate androstenedione has been thought to be important to the binding of aromatase and is also present in many inhibitors. However, some recent studies have shown that this group could be removed if some planarity were maintained in the steroid A-ring. ${ }^{16,18}$ For this reason, we prepared the 3-deoxy steroids 3a, 4a, and $\mathbf{4 b}$ (Schemes 1 and 2) having olefin and epoxy groups, that confer the desired planarity to the A-ring, and evaluated their inhibitory activity. We were also interested in studying the effect of the $\mathrm{C}-5$ stereochemistry of the $\mathrm{A} / \mathrm{B}$ ring fusion on drug-receptor interaction, so the $5 \alpha / \beta$ epimers $\mathbf{4 a} / \mathbf{4 b}$ and $\mathbf{5 a} / \mathbf{5 b}$ were prepared and evaluated. With respect to the steroid D-ring, there are not many modifications reported in the literature. However, some $\delta$-lactone D-ring steroids such as testolactone, the first steroidal aromatase inhibitor clinically used for breast cancer treatment (Figure 1), ${ }^{19}$ have also shown anti-

Scheme 2. Synthesis of Aromatase Inhibitors from $5 \alpha$ - and $5 \beta$-Olefins $\mathbf{3 a}$ and $\mathbf{3 b}^{a}$

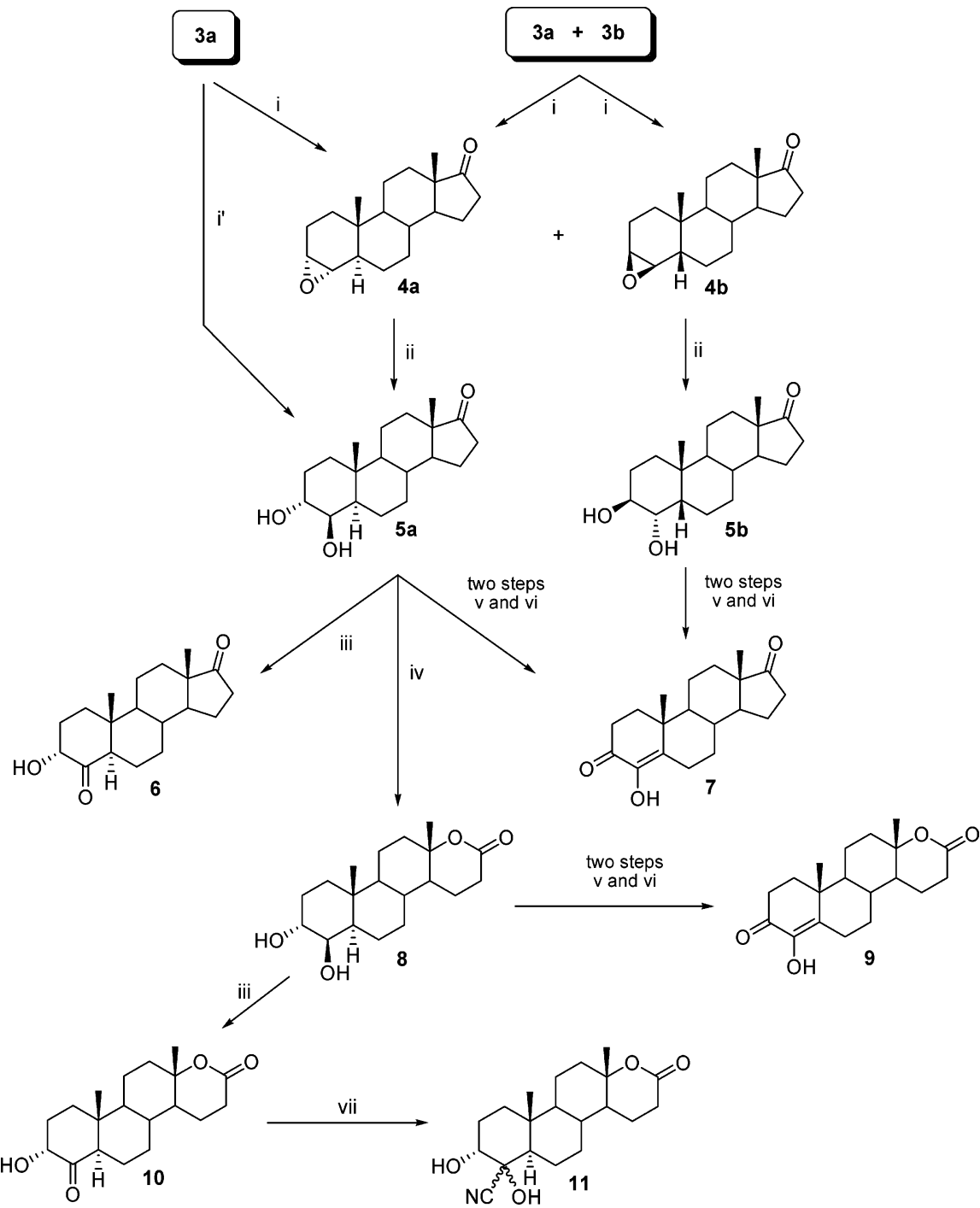

a (i) $\mathrm{H}_{2} \mathrm{O}_{2}, \mathrm{HCO}_{2} \mathrm{H}, \mathrm{CH}_{2} \mathrm{Cl}_{2}$, room temperature (RT), $6 \mathrm{~h}$; (i') $\mathrm{HCO}_{2} \mathrm{H}, \mathrm{H}_{2} \mathrm{O}_{2}, \mathrm{RT}, 1 \mathrm{~h}$; (ii) $\mathrm{HCO}_{2} \mathrm{H}, \mathrm{RT}, 30$ min; (iii) $\mathrm{AlO}_{3}$, oxone, $\mathrm{CH}_{2} \mathrm{Cl}_{2}$, $\mathrm{MeOH}, \mathrm{RT}, 6 \mathrm{~h}$; (iv) MMPP, $\mathrm{MeOH}, \mathrm{H}_{2} \mathrm{O}, \mathrm{RT}, 72 \mathrm{~h}$; (v) DMSO, TFAA, $-60^{\circ} \mathrm{C}, 3 \mathrm{~h}$, and then $\mathrm{Et}_{3} \mathrm{~N},-60^{\circ} \mathrm{C}, 15 \mathrm{~min}$; (vi) $\mathrm{HCl}, \mathrm{CH}_{3} \mathrm{COOH}$, $\mathrm{RT}, 24 \mathrm{~h}$; (vii) $\left(\mathrm{CH}_{3}\right)_{2} \mathrm{C}(\mathrm{OH}) \mathrm{CN}, \mathrm{Et}_{3} \mathrm{~N}, \mathrm{RT}, 6 \mathrm{~h}$. 
aromatase activity. On the basis of these, we decided to prepare and evaluate the $\delta$-lactone D-ring steroids 8, 9, 10, and 11 (Scheme 2). Furthermore, successful efforts have been made to combine in the same structure the diosphenol A-ring of formestane and the $\delta$-lactone D-ring of testolactone, as observed in compound $\mathbf{9}$.

\section{Results}

Chemistry. All steroids were prepared from androstenedione 1 by the routes depicted in Schemes 1 and 2 . The A-ring lactone aldehyde $\mathbf{2}$ was first obtained as a byproduct in a synthetic route for aromatase inhibitors previously developed in our laboratory. It was formed through a rearrangement, which occurred after controlled oxidation of $\mathbf{1}$ in methanol with alkaline potassium permanganate (Tavares da Silva, unpublished results). Clemmenson-type reduction of 1 with zinc dust in acetic acid solution afforded the isomeric mixture (2.3: 1 , by NMR) of the $5 \alpha$ - and $5 \beta$-olefins $\mathbf{3 a}$ and $\mathbf{3 b}$ in almost quantitative yield. Separation of the pure $\mathbf{3 a}$ $(60 \%)$ from the mixture was achieved by $n$-hexane crystallization. ${ }^{20}$

Treatment of $5 \alpha$-androst-3-en-17-one $\mathbf{3 a}$ (Scheme 2) with performic acid generated in situ led, after workup, to the trans-diaxial diol, $3 \alpha, 4 \beta$-dihydroxy- $5 \alpha$-androstan17 -one $\mathbf{5 a}$, in $96 \%$ yield. The $3 \alpha, 4 \alpha$-epoxide $\mathbf{4 a}$ was also obtained from the reaction of $\mathbf{3 a}$ with performic acid but with methylene chloride as reaction solvent instead. In this case, due to the low solubility of the resulting formic acid in this solvent, further cleavage of the epoxide intermediate was prevented and $\mathbf{4 a}$ was the only product formed, also in near quantitative yield. Epoxide 4b was prepared as described for $4 \mathbf{a}$ but with a 1:3 mixture of $\mathbf{3 a}$ and $\mathbf{3 b}$ as starting material. The abovementioned mixture has been used as we could not isolate the pure $\mathbf{3 b}$ from it. Under these conditions a 1:3 mixture of epoxides $\mathbf{4 a}$ and $\mathbf{4 b}$ was obtained, from which $\mathbf{4 b}$ was easily isolated by crystallization. Treatment of $4 \mathbf{b}$ with $90 \%$ formic acid solution afforded a mixture of two other diols and of the desired 3,4-transdiaxial diol $\mathbf{5 b}$, which was isolated by crystallization or column chromatography in $48 \%$ yield. ${ }^{20}$ Swern-type oxidation of $\mathbf{5 a}$ with dimethyl sulfoxide, activated with trifluoroacetic anhydride, gave quantitatively kinetic diosphenol, the 3-hydroxy-5 $\alpha$-androst-2-ene-4,17-dione ${ }^{21}$ which by acid- or base-catalyzed isomerization with $\mathrm{HCl} / \mathrm{CH}_{3} \mathrm{COOH}$ or $\mathrm{NaOMe} / \mathrm{MeOH}$ led to the desired thermodynamic diosphenol 4-OHA 7 as the only product, formed in $80 \%$ yield. The same Swern-type oxidation applied to $5 \beta$-diol $\mathbf{5 b}$ afforded a mixture with a variable composition (1:2 to $2: 1$, by NMR) of a $5 \beta$-kinetic diosphenol, the 3 -hydroxy- $5 \beta$-androst-2-ene4,17 -dione, ${ }^{20}$ and an unstable triketone, the $5 \beta$-androstane-3,4,17-trione,${ }^{20}$ which after acid- or base-catalyzed isomerization were also converted in similar yield to diosphenol 7. Treatment of diol $\mathbf{5 a}$ in methylene chloride with oxone catalyzed with alumina in the heterogeneous phase allowed the selective oxidation of the C-4 hydroxyl group, affording the $\alpha$-ketol 6 . Baeyer-Villiger oxidation of the 17-keto group of $\mathbf{5 a}$ with monoperoxyphthalic acid magnesium salt hexahydrate (MMPP) yielded the dihydroxylactone derivative 8 in $90-94 \%$ yield. Further oxidation of $\mathbf{8}$ with dimethyl sulfoxide activated with trifluoroacetic anhydride gave a kinetic diosphenol, the
Table 1. Aromatase Inhibition by A/D-Ring Substituted Steroids $^{a}$

\begin{tabular}{lc}
\hline \multicolumn{1}{c}{ compound } & inhibition $(\%)$ for $2 \mu \mathrm{M}$ \\
\hline $\mathbf{2}$ & $11.0 \pm 1.9$ \\
$\mathbf{3 a}$ & $95.9 \pm 0.6$ \\
$\mathbf{4 a}$ & $96.4 \pm 0.1$ \\
$\mathbf{4 b}$ & $14.6 \pm 1.6$ \\
$\mathbf{5 a}$ & $34.6 \pm 1.0$ \\
$\mathbf{5 b}$ & $10.1 \pm 1.8$ \\
$\mathbf{6}$ & $83.3 \pm 1.3$ \\
$\mathbf{7}$ (formestane) & $99.1 \pm 0.04$ \\
$\mathbf{8}$ & $8.1 \pm 1.8$ \\
$\mathbf{9}$ & $72.5 \pm 1.7$ \\
$\mathbf{1 0}$ & $16.6 \pm 1.5$ \\
$\mathbf{1 1}$ & $17.6 \pm 1.6$ \\
\hline
\end{tabular}

${ }^{a}$ Concentrations of $40 \mathrm{nM}\left[1 \beta^{3} \mathrm{H}\right]$ androstenedione, $20 \mu \mathrm{g}$ of protein from human placental microsomes, and $2 \mu \mathrm{M}$ inhibitor and 15 min incubation were used. Results are the mean of at least three independent experiments done in triplicate.

3-hydroxy-D-homo-17a-oxa-5 $\alpha$-androsta-2-ene-4,17-dione ${ }^{22}$ which after acid-catalyzed isomerization yielded quantitatively the thermodynamic diosphenol 9. Oxidation of $\mathbf{8}$ in heterogeneous phase with the oxone alumina system (also used previously for the diol $\mathbf{5 a}$ ) gave the $\alpha$-ketol 10. Treatment of $\mathbf{1 0}$ with acetone cyanohydrin and triethylamine provided the lactone cyanohydrin derivative 11.

Biochemical Properties. Inhibition of aromatase activity by the newly prepared A- and D-ring modified steroids was evaluated in human placental microsomes by a radiometric assay in which tritiated water, released from $\left[1 \beta-{ }^{3} \mathrm{H}\right]$ androstenedione into the incubation medium, was used as an index of estrogen formation. ${ }^{23}$ The results of these studies are shown as percentage of inhibition for all compounds at $2 \mu \mathrm{M}$, relative to an assay in the absence of an inhibitor (Table 1). The wellknown aromatase inhibitor 4-hydroxyandrostenedione (Figure 1), with an inhibitory capacity of $99.1 \% \pm 0.04 \%$, was used as reference. For the inhibitors showing antiaromatase activity equal to or higher than $70 \%(\mathbf{3 a}, \mathbf{4 a}$, $\mathbf{6}$, and $\mathbf{9}), \mathrm{IC}_{50}$ was determined in saturating concentrations $(200 \mathrm{nM})$ of androstenedione. In addition, the type of binding to the active site of aromatase was characterized and the apparent inhibition constant $\left(K_{\mathrm{i}}\right)$ was determined by use of different inhibitor and substrate concentrations. The inhibition kinetic studies were performed with human placental microsomes and the results were plotted as Lineweaver-Burk plots. The inhibition type of all compounds tested was competitive. A representative Lineweaver-Burk plot of aromatase inhibition is shown in Figure 2 for compound 9. The apparent inhibition constants $\left(K_{\mathrm{i}}\right)$, which characterize the enzyme affinity, were obtained by Dixon plots (Figure 3). The $\mathrm{IC}_{50}$ value for formestane was evaluated in our test system and used for comparison. This compound presented higher inhibitory activity than all the synthesized compounds. The $\mathrm{IC}_{50}, K_{\mathrm{i}}$, type of inhibition and $K_{\mathrm{m}} / K_{\mathrm{i}}$ ratios for the more active inhibitors are shown in Table 2. In these studies, the apparent $K_{\mathrm{m}}$ and $V_{\max }$ values for aromatase with androstenedione as

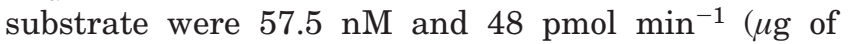
protein $)^{-1}$, respectively.

\section{Discussion}

Compound 3a, the $5 \alpha$-epimer of the 3,4-olefin, showed $95.9 \% \pm 0.6 \%$ rate of inhibition. It is a strong inhibitor 


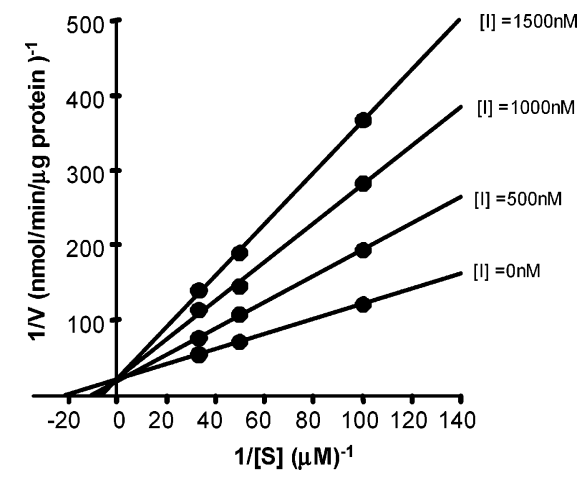

Figure 2. Lineweaver-Burk plot of inhibition of human placental aromatase by inhibitor 9 with androstenedione as substrate. Each point represents the mean of three determinations. The inhibition experiments with the other compounds gave similar plots to the results shown for $\mathbf{9}$.

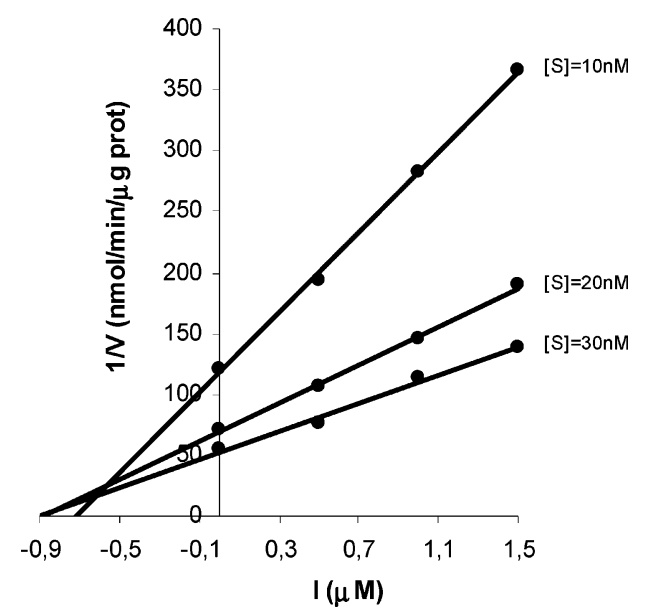

Figure 3. Dixon plots to determine the apparent inhibition constant $\left(K_{\mathrm{i}}\right)$ for inhibitor $\mathbf{9}$.

Table 2. In Vitro Aromatase Inhibition

\begin{tabular}{|c|c|c|c|c|}
\hline inhibitor & $\begin{array}{l}\mathrm{IC}_{50^{a}} \\
(\mu \mathrm{M})\end{array}$ & $\begin{array}{c}K_{\mathrm{i}}^{b} \\
(\mathrm{nM})\end{array}$ & $\begin{array}{c}\text { type of } \\
\text { inhibition }^{c}\end{array}$ & $\begin{array}{l}\text { rel affinity } \\
\left(K_{\mathrm{m}} / K_{\mathrm{i}}\right)\end{array}$ \\
\hline 9 & 1.850 & 660 & competitive & 0.087 \\
\hline $3 a$ & 0.225 & 50 & competitive & 1.15 \\
\hline $4 a$ & 0.145 & 38 & competitive & 1.51 \\
\hline 6 & 0.670 & 147 & competitive & 0.39 \\
\hline 7 (formestane) & 0.042 & & & \\
\hline
\end{tabular}

${ }^{a}$ Concentrations of $200 \mathrm{nM}\left[1 \beta-{ }^{3} \mathrm{H}\right]$ androstenedione and $20 \mu \mathrm{g}$ of protein from human placental microsomes were used. ${ }^{b}$ Inhibition constant was obtained by Dixon plot. In these experiments, the $K_{\mathrm{m}}$ for the substrate androstenedione was found to be 57.5 nM. ${ }^{c}$ The inhibitors studied showed competitive inhibition on the basis of analysis of the Lineweaver-Burk plot.

of aromatase with an $\mathrm{IC}_{50}=225 \mathrm{nM}$ and has higher affinity for the enzyme than its natural substrate androstenedione $\left(K_{\mathrm{i}}=50 \mathrm{nM}\right.$ versus $K_{\mathrm{m}}=57.5 \mathrm{nM}$, respectively). Compound $4 \mathbf{a}$, the $5 \alpha$-epimer of the 3,4epoxide, showed $96.4 \% \pm 0.1 \%$ inhibition of aromatase, revealing it to be the best competitive inhibitor among all the compounds studied in this work. This epoxide 4a presented an $\mathrm{IC}_{50}=145 \mathrm{nM}$ and was found to bind the enzyme with an affinity 1.5 times higher $\left(K_{\mathrm{i}}=38\right.$ $\mathrm{nM})$ than that of the natural substrate $(57.5 \mathrm{nM})$. Numazawa et al. ${ }^{16}$ have already reported that 3-deoxy4-ene and 3-deoxy-5-ene derivatives of androstenedione are competitive inhibitors of aromatase. In this work we pointed out that, in addition to these derivatives, the 3-deoxy-3-ene derivative $\mathbf{3 a}$ of androstenedione is also a strong competitive inhibitor of aromatase. Furthermore, the 3,4-epoxide derivative $\mathbf{4 a}$, which has the same stereochemistry requirements in the A-ring, is also a strong competitive aromatase inhibitor. These results stress the importance of A-ring planarity in the interaction with the active site of the enzyme. The lack of a C-3 carbonyl group in these compounds also indicates that this feature is not a determinant for inhibition, as previously observed by Numazawa. ${ }^{16,24}$ Compound 5a, the $5 \alpha$-epimer of a 3,4-diol, showed an inhibition of $34.6 \% \pm 1.0 \%$, and its 4 -keto derivative, the $\alpha$-ketol $\mathbf{6}$, showed a significant increase in the inhibitory capacity of $83.3 \% \pm 1.3 \%$. These results demonstrate, once more, the importance of the planarity in the A-ring for the inhibition, now conferred by a C-4 carbonyl group in 6 . Compound 2, a 4-oxa steroid with a $5 \alpha$-aldehyde group showed only $11.0 \% \pm 1.9 \%$ inhibition. In this way, more studies should be performed in order to understand the influence of 4-oxa and $5 \alpha$-aldehyde groups in the antiaromatase activity.

The effect of the C-5 stereochemistry on the inhibition of aromatase was studied for the $5 \alpha / \beta$-epimers $\mathbf{4 a} / \mathbf{4 b}$ and $\mathbf{5 a} / \mathbf{5 b}$. Within the 3,4-epoxide derivatives $\mathbf{4 a}$ and $\mathbf{4 b}$, the $5 \alpha$-substituted steroid $\mathbf{4 a}$ showed $96.4 \%$ aromatase inhibition in contrast to the corresponding $5 \beta$ epimer 4b, which had a dramatic reduction in inhibition $(14.6 \% \pm 1.6 \%)$. Within compounds $\mathbf{5 a}$ and $\mathbf{5 b}$, the $5 \alpha-$ epimer of the 3,4-diol $\mathbf{5 a}$ inhibited aromatase 34.6\%, whereas the correspondent $5 \beta$-epimer $\mathbf{5 b}$ showed a decrease in the inhibitory activity $(10.1 \% \pm 1.8 \%)$. These results indicate that the angle formed in the A/B-ring junction is crucial in order to better fit the enzymatic active site. The $5 \beta$-epimers, in which $\mathrm{A}$ - and $\mathrm{B}$-rings are almost perpendicular, will not be well accommodated by the enzyme.

The effect of the D-ring modification in the inhibition of aromatase was observed in steroids $\mathbf{8 ,}, \mathbf{9}$, and 10, in which six-membered $\delta$-lactone rings were introduced. Compound 9, combining the diosphenol A-ring of the potent inhibitor formestane and the $\delta$-lactone D-ring of testolactone (Figure 1), showed 72.5\% aromatase inhibition and an $\mathrm{IC}_{50}=1.85 \mu \mathrm{M}$, compared to $99.1 \% \pm 0.04 \%$ and $\mathrm{IC}_{50}=0.042 \mu \mathrm{M}$ for formestane. Similar reduction in the inhibitory capacity was observed for the pair of compounds $\mathbf{6}$ and 10, which showed inhibitory activities of $83.3 \% \pm 1.3 \%$ and $16.6 \% \pm 1.5 \%$, respectively. Compound 6 was a competitive inhibitor of aromatase, with $\mathrm{IC}_{50}=670 \mathrm{nM}$. It blocks the enzyme activity to a much greater extent than the corresponding D-ring lactone compound $10\left(\mathrm{IC}_{50}>100 \mu \mathrm{M}\right)$. In the same way, compound 5a showed an inhibitory activity of $34.6 \% \pm$ $1.0 \%$, while the introduction of the $\delta$-lactone ring, yielding derivative $\mathbf{8}$, strongly affects inhibition (8.1\% $\pm 1.8 \%$ ). These results suggest that the inhibitory activity of testolactone is probably not due to its $\delta$-lactone D-ring. Compound 11, the 4-cyano derivative of $\mathbf{8}$, showed a slight increase in the inhibitory activity (17.6\% $\pm 1.6 \%$ ) compared to its precursor. The chemically reactive cyano group in the $\mathrm{C}-4$ position of this compound is also present in the most recent third generation cyano azole-type aromatase inhibitors ${ }^{25}$ revealing it to be an important feature for enzyme inhibition. This result also indicates that the $\mathrm{C}-4$ position is a critical region for the interaction of steroids with aromatase. 


\section{Conclusions}

Our data showed that modification in the A- and D-rings of androstenedione provides potent, easily available, and structurally simple aromatase inhibitors. Nevertheless, none of the compounds prepared was shown to be a stronger inhibitor than formestane. Only specific changes were allowed in the A-ring of steroids in order to obtain potent inhibitors. The C-3 carbonyl is not a determinant group for the interaction of the studied steroids with the enzyme and for its inhibition. In fact, the 3-deoxy compounds $\mathbf{3 a}$ and $\mathbf{4 a}$ were demonstrated to be strong competitive inhibitors of aromatase. They have also shown higher affinity toward the enzyme than its natural substrate androstenedione. These results suggest that a 3,4-double bond or a 3,4epoxide group will confer the A-ring planarity required for anti-aromatase activity, according to the previous observations by Numazawa and co-workers. ${ }^{15-18,24}$ Epoxide 4a proved to be the most potent inhibitor, revealing that, in addition to planarity, the oxygen atom near the C-4 region will be important for activity. A C-4 carbonyl group, as observed in 6, may also contribute to the above-mentioned requirements for anti-aromatase activity. In addition to planarity in the A-ring, planarity in the A/B-ring junction of the steroids seems also to be important for enzyme inhibition. Our results therefore stress that the $5 \alpha$-stereochemistry is required for inhibition. Concerning the D-ring, the replacement of the original steroid cyclopentanone ring by a six-membered $\delta$-lactone ring reduces the inhibitory activity. The magnitude of this reduction seems to be also dependent on the substitution pattern in the A-ring, as observed for compounds $\mathbf{8 , 9}$, and $\mathbf{1 0}$. This modification in the D-ring may induce structural alterations in the steroidal framework, affecting their ability to bind to the active site of the enzyme.

The preliminary biological profile indicates that it is important to synthesize new steroid derivatives in order to refine the encountered SAR for the prepared compounds.

\section{Experimental Section}

Chemistry: 3,17-Dioxo-4-oxaandrostane-5 $\alpha$-carbaldehyde (2). To a cold $\left(-5^{\circ} \mathrm{C}\right)$ stirred solution of androst-4-ene3,17-dione $\mathbf{1}(3.0 \mathrm{~g}, 10.5 \mathrm{mmol})$ in $200 \mathrm{~mL}$ of methanol, a $2.5 \%$ solution of potassium permanganate in aqueous $\mathrm{KOH}, 0.05 \mathrm{~N}$ (130 mL, $20.6 \mathrm{mmol})$, was added dropwise. The temperature was then raised to $15^{\circ} \mathrm{C}$ and after $5-10$ min the excess oxidant was destroyed with saturated aqueous $\mathrm{Na}_{2} \mathrm{~S}_{2} \mathrm{O}_{5}(20 \mathrm{~mL})$. After separation of the formed $\mathrm{MnO}_{2}$ by centrifugation, the methanol was evaporated and the solution diluted with water $(200 \mathrm{~mL})$, neutralized with aqueous $1 \mathrm{~N} \mathrm{H}_{2} \mathrm{SO}_{4}$, and extracted with $\mathrm{CH}_{2-}$ $\mathrm{Cl}_{2}(3 \times 100 \mathrm{~mL})$. The organic extract was washed with $10 \%$ aqueous $\mathrm{Na}_{2} \mathrm{~S}_{2} \mathrm{O}_{5}(100 \mathrm{~mL})$ and then water $(2 \times 100 \mathrm{~mL})$, dried $\left(\mathrm{MgSO}_{4}\right)$, and evaporated to dryness to give $1.36 \mathrm{~g}(41 \%)$ of a crude product from where the title compound $\mathbf{2}$ was isolated by crystallization from absolute ethanol.

$5 \alpha$ - and $5 \beta$-Androst-3-en-17-one (3a and $3 b)$. The title olefins $\mathbf{3 a}$ and $\mathbf{3 b}$ were prepared from androst-4-ene-3,17-dione $1(500 \mathrm{mg}, 1.75 \mathrm{mmol})$ through a Clemmenson-type reduction with zinc dust in acetic acid, according to the reaction conditions previously described. ${ }^{20}$ The crude product obtained as a white crystalline solid $(476 \mathrm{mg}$ ) was composed of an isomeric mixture (2.3:1 by NMR) of $5 \alpha$-olefin $3 \mathbf{a}$ and $5 \beta$-olefin 3b. Crystallization of the mixture from $n$-hexane gave the pure $\mathbf{3 a}(285 \mathrm{mg}, 60 \%)$. The $5 \beta$-epimer $\mathbf{3 b}$ could not be isolated and has been identified in the mixture with the $5 \alpha$-epimer only by ${ }^{1} \mathrm{H}$ and ${ }^{13} \mathrm{C} \mathrm{NMR}$.
3 $\alpha, 4 \alpha$-Epoxy-5 $\alpha$-androstan-17-one (4a). The title compound $4 \mathbf{a}$ was prepared from oxidation of olefin $3 \mathbf{a}(67.5 \mathrm{mg}$, $0.25 \mathrm{mmol}$ ) in methylene chloride with performic acid generated in situ with $30 \%$ hydrogen peroxide $(0.05 \mathrm{~mL}, 0.5 \mathrm{mmol})$ and $90 \%$ formic acid $(0.05 \mathrm{~mL}, 1.18 \mathrm{mmol})$, according to the reaction conditions previously described..$^{20}$ Epoxide $4 \mathbf{a}(75 \mathrm{mg}$, $96 \%$ ) was obtained as the only isolated product identified.

3/,4/-Epoxy-5 $\beta$-androstan-17-one (4b). The title epoxide 4b was prepared as described above for $\mathbf{4 a}$ but with a mixture of olefins $3 \mathbf{a}$ and $\mathbf{3 b}$ (1:3 by NMR) as the starting material. Under these conditions, a 1:3 mixture of $\mathbf{4 a}$ and $\mathbf{4 b}$ was obtained, from which $\mathbf{4} \mathbf{b}$ was isolated by slow diethyl ether crystallization.

3 $\alpha, 4 \beta$-Dihydroxy-5 $\alpha$-androstan-17-one (5a). The title $5 \alpha$ vic-diol $\mathbf{5 a}(75 \mathrm{mg}, 96 \%)$ was prepared from olefin $\mathbf{3 a}(67.5$ $\mathrm{mg}, 0.25 \mathrm{mmol}$ ) by oxidation with the in situ generated performic acid and isolated according to the reaction conditions previously described. ${ }^{21}$

3/,4 $\alpha$-Dihydroxy-5 $\beta$-androstan-17-one (5b). The title $5 \beta$ vic-diol $\mathbf{5 b}$ was obtained in a mixture with two other diols, by cleavage of epoxide $4 \mathbf{b}(200 \mathrm{mg}, 0.69 \mathrm{mmol})$ with formic acid and was separated (102 mg, 48\%) by column chromatography, according to the reaction conditions previously described. ${ }^{20}$

$3 \alpha$-Hydroxy- $5 \alpha$-androstane-4,17-dione (6). To a solution of $3 \alpha, 4 \beta$-dihydroxy- $5 \alpha$-androstan- 17 -one $\mathbf{5 a}(50 \mathbf{~ m g}, 0.16 \mathrm{mmol})$ in methylene chloride with some drops of methanol $(1.7 \mathrm{~mL})$ were added wet alumina $(335 \mathrm{mg})$ and oxone $(252 \mathrm{mg}, 0.41$ $\mathrm{mmol}$ ). The suspension was sonicated under inert atmosphere in a cleaning bath ("Bandelin", $450 \mathrm{~W}, 35 \mathrm{kHz}$ ) at $22{ }^{\circ} \mathrm{C}$ until the steroid was consumed [30 min, thin-layer chromatogtaphy (TLC)]. After dilution with methylene chloride, the suspension was filtered, washed with aqueous $\mathrm{HCO}_{3} \mathrm{Na}$ and water, dried over magnesium sulfate, and evaporated to dryness to give a crude extract ( $43 \mathrm{mg}, 87 \%$ ) from which the title compound was isolated by crystallization.

4-Hydroxyandrost-4-ene-3,17-dione (7): (i) Oxidation of Diols 3 $\alpha, 4 \beta$-Dihydroxy-5 $\alpha$-androstan-17-one (5a) and

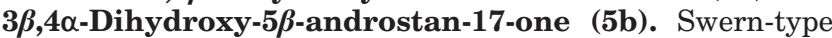
oxidation of the $5 \alpha$-vic-diol $5 \mathrm{a}(203 \mathrm{mg}, 0.66 \mathrm{mmol})$ with dimethyl sulfoxide (DMSO; $0.15 \mathrm{~mL}, 2.11 \mathrm{mmol}$ ) and trifluoroacetic anhydride $(0.27 \mathrm{~mL}, 1.91 \mathrm{mmol})$, according to the reaction conditions previously described, ${ }^{20}$ yielded a crude $5 \alpha$ kinetic diosphenol, the 3-hydroxy-5 $\alpha$-androst-2-ene-4,17-dione (199 mg, 98\%), which was purified by column chromatography.

The same oxidative conditions used for the $5 \alpha$-vic-diol 5a were applied to the $5 \beta$-vic-diol $\mathbf{5 b}$, giving a mixture with a variable composition (1:2 to $2: 1$ by NMR) of a $5 \beta$-triketone, the $5 \beta$-androstane-3,4,17-trione, and a $5 \beta$-kinetic diosphenol, the 3 -hydroxy- $5 \beta$-androst-2-ene-4,17-dione. ${ }^{20}$ The unstable above-mentioned $5 \beta$-kinetic diosphenol and the triketone could not be separated because of their rapid conversion into diosphenol 7 .

(ii) Isomerization of the Kinetic $5 \alpha$ - and $5 \beta$-Diosphenols and $\mathbf{5} \boldsymbol{\beta}$-Triketone. The title diosphenol $\mathbf{7}$ was prepared in a convergent manner by isomerization of the $5 \alpha$ - and $5 \beta$ kinetic diosphenols and $5 \beta$-triketone, previously obtained (60 $\mathrm{mg}, 0.2 \mathrm{mmol}$ ) in methanol solution with sodium metal (50 $\mathrm{mg}, 2.2 \mathrm{mmol}$ ) according to the conditions previously described. ${ }^{20}$ The crude crystalline product obtained was purified by flash chromatography [silica gel; diethyl ether-carbon tetrachloride (1:1)] to give $48 \mathrm{mg}$ of $\mathbf{7}(80 \%)$.

$3 \alpha, 4 \beta$-Dihydroxy-D-homo-17a-oxa-5 $\alpha$-androstan-17one (8). The title dihydroxylactone 8 was obtained as a pure white crystalline solid in a 90-94\% yield by oxidation of diol $\mathbf{5 a}(50 \mathrm{mg}, 0.16 \mathrm{mmol})$ with magnesium monoperoxyphthalate $(7-10 \mathrm{~mol} / \mathrm{mol}$ of substrate), according to the reaction conditions described previously. ${ }^{22}$

4-Hydroxy-D-homo-17a-oxaandrost-4-ene-3, 17-dione (9). Swern-type oxidation of the dihydroxylactone $8(400 \mathrm{mg}$, $1.24 \mathrm{mmol})$ with DMSO $(0.3 \mathrm{~mL}, 4.22 \mathrm{mmol})$ activated with trifluoroacetic anhydride $(0.54 \mathrm{~mL}, 3.82 \mathrm{mmol})$, according to the reaction conditions previously described ${ }^{22}$ yielded almost quantitatively a kinetic diosphenol, the 3-hydroxy-D-homo17a-oxa-5 $\alpha$-androst-2-ene-4,17-dione, ${ }^{22}$ (387 mg, 98\%) which, 
by further acid-catalyzed isomerization, was quantitatively (99\%) converted in the title thermodynamic diosphenol 9.

$3 \alpha$-Hydroxy-17a-oxa-17a-homo-5 $\alpha$-androstane-4, 17-dione (10). To a solution of the dihydroxylactone 8 (100 $\mathrm{mg}, 0.31$ $\mathrm{mmol})$ in analar methylene chloride $(2.0 \mathrm{~mL})$, and 10 drops of methanol were added alumina $\left[\mathrm{AlO}_{3}\right.$, W200 acid activity super I $\left.\left(0 \% \mathrm{H}_{2} \mathrm{O}\right), 335 \mathrm{mg}\right]$ and oxone $(250 \mathrm{mg}, 0.41 \mathrm{mmol})$. The suspension was stirred at room temperature $\left(18^{\circ} \mathrm{C}\right)$ until the steroid was consumed ( $6 \mathrm{~h}$, TLC, ethyl acetate $/ n$-hexane 5:1). After dilution with dried $\left(\mathrm{MgSO}_{4}\right)$ methylene chloride, the suspension was filtered and the filtrate was washed with the same solvent $(200 \mathrm{~mL})$ and evaporated to dryness to give a crude white solid (97-99 mg, 97.6-99.6\%), from which the pure title $\alpha$-ketol-lactone $\mathbf{1 0}$ was isolated by crystallization.

$4 \xi$-Cyano-3 $\alpha, 4 \xi$-dihydroxy-17a-oxa-17a-homo-5 $\alpha$-androstan-17-one (11). To $50 \mathrm{mg}(0.156 \mathrm{mmol})$ of the $\alpha$-ketollactone 10 were added acetone cyanohydrin $(99.5 \mu \mathrm{L}, 1.08$ mmol) and triethylamine $(7.75 \mu \mathrm{L})$, and the suspension was stirred at room temperature for $4 \mathrm{~h}$ until the reaction was complete (TLC). The reaction mixture was then poured into water $(5-10 \mathrm{~mL})$ with ice $(5-10 \mathrm{~g})$ and acetic acid $(0.25-0.5$ $\mathrm{mL}$ ) under magnetic stirring. The precipitated product was filtered, washed with water followed by methylene chloride, and crystallized from ethyl acetate, giving the title cyanohydrin $\mathbf{1 1}$ as a white powder.

Biochemistry: Preparation of Placental Microsomes. Placental microsomes were obtained as described by Yoshida and Osawa ${ }^{26}$ with some modifications. Human placentas obtained after delivery from a local hospital were placed in cold $67 \mathrm{mM}$ potassium phosphate buffer ( $\mathrm{pH}$ 7.4) containing $1 \% \mathrm{KCl}$. The cotyledon tissue was separated and homogenized in a Polytron homogenizer with $67 \mathrm{mM}$ potassium phosphate buffer ( $\mathrm{pH}$ 7.4) containing $0.25 \mathrm{M}$ sucrose and $0.5 \mathrm{mM}$ dithiothreitol (DTT, 1:1 w/v). The homogenate was centrifuged at $5000 \mathrm{~g}$ for $30 \mathrm{~min}$. The supernatant was centrifuged twice at $20000 \mathrm{~g}$ for $30 \mathrm{~min}$ and at $148000 \mathrm{~g}$ for $45 \mathrm{~min}$ to yield a microsomal pellet. The microsomes were washed and resuspended in $67 \mathrm{mM}$ potassium phosphate buffer $(\mathrm{pH} 7.4)$ containing $0.25 \mathrm{M}$ sucrose, $20 \%$ glycerol, and $0.5 \mathrm{mM}$ DTT and stored at $-80{ }^{\circ} \mathrm{C}$. All procedures were carried out at $0-5{ }^{\circ} \mathrm{C}$. Protein content was estimated by the Bradford method, ${ }^{27}$ with bovine serum albumin (BSA) as standard. No significant enzyme activity loss occurred after 6 months.

Aromatase Assay Procedure. Aromatase activity was measured according to Thompson and Siiteri ${ }^{23}$ and Heidrich et al. ${ }^{28}$ Aromatase activity was evaluated by measuring the ${ }^{3} \mathrm{H}_{2} \mathrm{O}$ released from $\left[1 \beta-{ }^{3} \mathrm{H}\right]$ androstenedione during aromatization. All tested compounds were dissolved in ethanol and diluted in $67 \mathrm{mM}$ potassium phosphate buffer ( $\mathrm{pH}$ 7.4). Briefly, for the screening assay, $20 \mu \mathrm{g}$ of protein of the microsomes, $40 \mathrm{nM}\left[1 \beta-{ }^{3} \mathrm{H}\right]$ androstenedione $(1 \mu \mathrm{Ci})$ purchased from PerkinElmer Life Sciences, and $2 \mu \mathrm{M}$ each of the inhibitors were used, while for the $\mathrm{IC}_{50}$ determination, $200 \mathrm{nM}(1 \mu \mathrm{Ci})$ androstenedione and different concentrations of the inhibitors were used. The aromatase-catalyzed reaction was initiated by the addition of reduced nicotinamide adenine dinucleotide phosphate (NAD$\mathrm{PH}, 150 \mu \mathrm{M}$ ), and incubations were performed in a shaking water bath at $37^{\circ} \mathrm{C}$ for $15 \mathrm{~min}$. However, to minimize the timedependent loss of the initial aromatization rate, $10-30 \mathrm{nM}$ $\left[1 \beta-{ }^{3} \mathrm{H}\right]$ androstenedione and $5 \mathrm{~min}$ incubation time were used for the kinetic studies. The reaction was terminated by addition of $500 \mu \mathrm{L}$ of ice-cold distilled water and $1.5 \mathrm{~mL}$ of ice-cold chloroform. After centrifugation at $3200 \mathrm{~g}$ for $10 \mathrm{~min}$, the aqueous phase was added to $5 \%$ charcoal $/ 0.5 \%$ dextran coated. After a new centrifugation cycle, the resulting supernatant was mixed with $1.5 \mathrm{~mL}$ of chloroform and centrifuged. The purified aqueous supernatant containing ${ }^{3} \mathrm{H}_{2} \mathrm{O}$ was mixed with a liquid scintillation cocktail (Universol) and counted in a Beckman liquid scintillation spectrometer (LS6500). All experiments were carried out in triplicate.

Acknowledgment. We thank Professor Martinez Oliveira and Dr. Isabel Campos of São João Hospital, Oporto, for generously supplying human term placenta.
This work was supported by Fundação para a Ciência e Tecnologia (FCT), Portugal. M.M.D.S.C. is a recipient of a Ph.D. grant of FCT (SFRH/BD/10736/2002). We also thank Novartis Farma-Produtos Farmacêuticos S.A., Portugal, for kindly supplying formestane for use as a reference substance.

Supporting Information Available: Elemental analysis results for compounds $\mathbf{2}, \mathbf{5 a}$, and $\mathbf{9}$; HRMS data for compounds 4b and 5b; EIMS $m / z\left(\mathrm{M}^{+}\right)$data for compounds $4 \mathbf{a}, \mathbf{5 a}, \mathbf{6}$, and 8; melting points for compounds $\mathbf{2}, \mathbf{3 a}, \mathbf{4 a}-\mathbf{5 b}$, and 7-9; IR spectral data for compounds $\mathbf{2}, \mathbf{3 a}$, and $\mathbf{4 a}-\mathbf{9}$; and ${ }^{1} \mathrm{H}$ and ${ }^{13} \mathrm{C}$ spectroscopic data for compounds 2-11. This material is available free of charge via the Internet at http://pubs.acs.org.

\section{References}

(1) Miller, W. R. Biological Rational for Endocrine Therapy in Breast Cancer. Best Pract. Res. Clin. Endocrinol. Metab. 2004, 18, 1-32.

(2) Henderson B. E.; Ross R. K.; Pike M. C.; Casagrande, J. T. Endogenous Hormones as a Major Factor in Human Cancer. Cancer Res. 1982, 42, 3232-3239.

(3) Sedlacck, S. M.; Horwitz, K. B. The Role of Progestins and Progesterone Receptors in the Treatment of Breast Cancer. Steroids 1984, 44, 467-484.

(4) McGuire, W. R. An Update on Estrogen and Progesterone Receptors in Prognosis for Primary and Advanced Breast Cancer. In Hormones and Cancer; Iacobelli, S., King R. J. B., Linder H. R., et al., Eds.; Raven Press: New York, 1980; Vol. 14, pp 337344.

(5) Hemsell, D. L.; Grodin, J.; Breuner, P. F. Plasma Precursors of Estrogen. II. Correlation of the Extent of Conversion of Plasma Androstenedione to Estrone with Age. J. Clin. Endocrinol. Metab. 1974, 38, 476-479.

(6) Ackerman, G. E.; Smith M. E.; Mendelson, C. R.; MacDonald, P. C.; Simpson, E. R. Aromatization of Androstenedione by Human Adipose Tissue Stromal Cells in Monolayer Culture. $J$. Clin. Endocrinol. Metab. 1981, 53, 412-417.

(7) Miller, W. R.; Anderson, T. J.; Jack, W. J. L. Relationship Between Tumor Aromatase Activity, Tumor Characteristics and Response to Therapy. J. Steroid Biochem. Mol. Biol. 1990, 37 537-548.

(8) Njar, V. C. O.; Brodie, A. Comprehensive Pharmacology and Clinical Efficacy of Aromatase Inhibitors. Drugs 1999, 58, $233-$ 255.

(9) Zumoff, B. Does Postmenopausal Estrogen Administration Increase the Risk of Breast Cancer? Contributions of Animal, Biochemical and Clinical Investigative Studies to a Resolution of the Controversy. Proc. Soc. Exp. Biol. Med. 1998, 217, 3037.

(10) Winer, E. P.; Hudis, C.; Burstein, H. J.; Chebowski, R. T.; Ingle, J. N.; Edge, S. B.; Mamounas, E. P.; Gralow, J.; Goldstein, L. J.; Pritchard, K. I.; Cobleigh, M. A.; Langer, A. S.; Perotti, J. Powles, T. J.; Whelan, T. J.; Browman, G. P. Technology Assessment on the Use of Aromatase Inhibitors as Adjuvant Therapy for Women With Hormone Receptor-Positive Breast Cancer: Status Report 2002. J. Clin. Oncol. 2002, 20, 33173327

(11) Brodie, A. Aromatase Inhibitors and Hormone-Dependent Cancers. J. Steroid Biochem. Mol. Biol. 1990, 37, 327-333.

(12) Bulun, S. E.; Zeitoun, K.; Takayama, K.; Noble, L.; Michael, D.; Simpson, E.; Johns, A.; Putman, M.; Sasano, H. Estrogen Production in Endometriosis and Use of Aromatase Inhibitors to Treat Endometriosis. Endocr. Relat. Cancer 1999, 6, 293301.

(13) Miller, W. R.; Jackson, J. The Therapeutical Potential of Aromatase Inhibitors. Expert. Opin. Investig. Drugs 2003, 12, $337-52$.

(14) Goss, P. E.; Coombes, R. L.; Powles, T. J. Treatment of Advanced Postmenopausal Breast Cancer with Aromatase Inhibitor, 4-hydroxyandrostenedione - Phase 2 Report. Cancer Res. 1986, 46 , $4823-4826$

(15) Numazawa, M.; Yamaguchi, S. Synthesis and Structure-Activity Relationships of 6-Phenylaliphatic-Substitued C19 Steroids Having a 1,4-diene, 4,6-diene or 1,4,6-triene Structure as Aromatase Inhibitors. Steroids 2001, 64, 187-196.

(16) Numazawa, M.; Yamada, K.; Nitta, S.; Sasaki, C.; Kidokoro, K. Role of Hydrophilic Interaction in Binding of Hydroxylated 3-Deoxy C19 Steroids to the Active Site of Aromatase. J. Med. Chem. 2001, 44, 4277-4283 and references therein.

(17) Numazawa, M.; Yoshimura, A.; Watari, Y.; Matsuzaki, H. Aromatase Inhibition by $4 \beta, 5 \beta$-Epoxides of $16 \alpha$-Hydroxyandrostenedione and Its 19-Oxygenated Analogues, Potential Precursors of Estriol Production in the Feto-Placental Unit. Biol. Pharm. Bull. 2002, 25, 1566-1569. 
(18) Nagaoka, M.; Watari, Y.; Yajima, H.; Tsukioka, K.; Muroi, Y.; Yamada, K.; Numazawa, M. Structure-Activity Relationships of 3-Deoxy Androgens as Aromatase Inhibitors. Synthesis and Biochemical Studies of 4-Substituted 4-Ene and 5-Ene Steroids. Steroids 2003, 68, 533-542.

(19) Leclercq, G. Androgens and Other Androstane Derivatives: Aromatase Inhibitors; Lactones. In Antitumour Steroids: Blickenstaff, R. T., Ed.; Academic Press: New York, 1992; pp 65122.

(20) Tavares da Silva, E. J.; Roleira, F. M.; Sá e Melo, M. L.; Campos Neves, A. S.; Paixão, J. A.; Almeida, M. J.; Costa, M. M. R.; Andrade, L. C. R. X-ray and Deuterium Labeling Studies on the Abnormal Ring Cleavages of a $5 \beta$-Epoxide Precursor of Formestane. Steroids 2002, 67, 311-319.

(21) Tavares da Silva, E. J.; Sá e Melo, M. L.; Campos Neves, A. S. Novel Approach to the Synthesis of the Aromatase Inhibtor 4-Hydroxyandrost-4-ene-3, 17-dione (4-OHA). J. Chem. Soc., Perkin Trans. 1 1996, 14, 1649-1650.

(22) Tavares da Silva, E. J.; Sá e Melo, M. L.; Campos Neves, A. S.; Andrade, L. R. C.; Almeida, M. J. M.; Costa, M. M. R. Expedient Synthesis of Ring-D Lactones of Formestane and Related Androstanes as New Potential Aromatase Inhibitors. J. Chem. Soc., Perkin Trans. 1 1997, 23, 3487-3489.
(23) Thompson E. A.; Siiteri P. K. Utilization of Oxygen and Reduced Nicotimamide Adenine Dinucleotide Phosphate by Human Placental Microsomes During Aromatization of Androstenedione. Biol. Chem. 1974, 249, 53-64.

(24) Numazawa, M.; Mutsumi, A.; Tachibana, M.; Hoshi, K. Synthesis of Androst-5-en-7-ones and Androst-3,5-diene-7-ones and Their Related 7-Deoxy Analogues as Conformational and Catalytic Probes for the Active Site of Aromatase. J. Med. Chem. 1994, 37, 2198-2205.

(25) Narashimamurthy, J.; Rao, A. R. R.; Sastry, G. N. Aromatase Inhibitors: A New Paradigm in Breast Cancer Treatment. Curr. Med. Chem.-Anti-Cancer Agents 2004, 4 (6), 523-534.

(26) Yoshida N. Osawa Y. Purification of Human Placental Aromatase Cytochrome P-450 with Monoclonal Antibody and Its Characterization. Biochemistry 1991, 30, 3003-3010.

(27) Bradford, M. M. A Rapid and Sensitive Method for the Quantification of Microgram Quantities of Protein Utilizing the Principle of Protein-Dye Binding. Anal. Biochem. 1976, 72, 248-254.

(28) Heidrich, D.; Steckelbroeck, S.; Klingmuller, D. Inhibition of Human Cytochrome P-450 Aromatase Activity by Butylins. Steroids 2001, 66, 763-769.

JM050129P 